\title{
The Ideology Stance of the Jakarta Post through Headlines on Negara Islam Indonesia's Case
}

\author{
Sugeng Irianto ${ }^{1}$, Sukarno², Joko Sutopo ${ }^{3}$, Mursid Saleh ${ }^{4}$ \\ ${ }_{1,2,3,4}$ Graduate School, Universitas Negeri Semarang, Indonesia \\ ${ }^{1}$ Coresponding Email: sugengi05@yahoo.co.id
}

\begin{abstract}
This research is aimed to unfold the Ideology stance of the Jakarta Post when publishing the news on Negara Islam Indonesia (NII) case through its headlines. The data were headlines published in the Jakarta Post 2010-2014. This research was qualitative in nature, although simple quantitative also done to count the quantity of headlines and appraisal system. The qualitative was used to explain the ideology belongs to the Jakarta Post when publishing the news on NII. The study uses the model developed by White (2001) and Martin and Rose (2003) to reveal the ideology stance of the Jakarta Post. The result of this study is the Jakarta Post follows the government ideology by looking at the NII group as an illegal, terrorist, radical group which has to be eliminated. However, the Jakarta Post give the big portion (space) in the newspaper for the NII group through its headlines and national news to follow the Post policy to accommodate all the parties in Indonesia, specifically to minor groups or suppressed groups. This policy of the Jakarta Post reflects the democratic way as one of the vision of the Jakarta Post.
\end{abstract}

Keywords: ideology, Negara Islam Indonesia, the Jakarta Post, headlines

\section{Introduction.}

Negara Islam Indonesia or NII's case is of deep interest to the Indonesian news media, especially television and newspapers in Indonesia. The Indonesian newspaper's news on NII's case has special linguistic and rhetorical features that present the group as negative. Using Critical Discourse Analysis (CDA) perspective and analysis I want to reveal those linguistic and non linguistic factors (socio-politic) in the Jakarta Post's presentation of NII's case.

NII is an illegal (underground) Moslem organization in Indonesia which began its movement since the era of 1940s (before Indonesian independence, 1945) up to now. The organization used West Java province area to be the central part (basis) for its movement. NII was founded by Karto Suwiryo with the goal to set up an Islamic-ruled country within Indonesia, which would not allow freedom for other ways of life. Although the organization was banned by the Indonesian government and could be disintegrated by the Indonesian army, its underground movement continues struggling.

This study examines the Jakarta Post's news on NII for the following reasons: It is an internationally respected and available media source; the readers (specifically Indonesian people) are middle to upper level, mostly well educated people; Finally, the Jakarta Post is the main Indonesian (English written) newspaper which is read by all diplomats, expatriates, and other foreign people and democratic English speaking countries and is the first source of information (written) to know about Indonesian events for all these different groups.

The Purpose of the study is to seek to describe and explain how discourse structures operate in the Jakarta Post news on NII. I am looking specifically for ways that the discourse enacts, confirms, reproduces or challenges ideology in Indonesia in the case of NII as represented in the Jakarta Post. The Jakarta Post is one of Indonesian newspapers written in English which is widely accessible for local and global market. It was the first Indonesian newspaper written in English published in 1983 with aim at providing an Indonesian perspective to counter the highly unbalanced Western-dominated global traffic of news and views.

I try to discuss how selected headline texts from the Jakarta post expose its ideology or belief toward the topic of NII's case from Critical Discourse Analysis (CDA) perspective. This issue is exposed rapidly by media both 
electronic and newspaper as it is potentially consumptive. It seems that they try to present this hot topic as it to be persistent exists. However, as media function as a social means, they are expected to be neutral and proportional in conveying the news. They should not expose news based upon certain group's interest.

\section{Methods}

In this study, I collected the headlines and editorials of the Jakarta Post about NII. The unit of analysis of the study were words, phrases, clauses and argumentation development. Then displayed all the data into chunks or clauses to find out the appraisal system (affective, judgment, and value) both in positive and negative points of the appraisal.

Then counted the appraisal points (system) from all the data to draw the percentages of the items of the appraisal system refers to Rose and White method. The data of the texts were the major or primarily data and supported with the secondary data in the form of interviews with the boards of editor of the Jakarta Post I conducted.

\section{Result and Discussion}

Through the 23 headlines text about NII, it could be found that:

a. The generic structure of the data (headlines and editorials) was the news items which have been divided into three parts: (1) main events, (2) elaborations, and (3) source.

b. The communicative purposes of the texts were: (1).To tell the readers that the terrorist escapes new tricky to strengthen their link, (2). To explain the readers that a big number of students have been affected by NII, (3).To tell readers that terrorists have shaped underground movement, especially at campus (4).To informs the readers about new trend of terrorism (from Moslem boarding traditional schools or " pesantren" to campuses) (6). To show the readers that some certain universities rejected NII strictly.

c. Some language features which were found: (1). Saying verb, which were represented by the word "said". In every single headline, there would be more than 7 saying verb of 'said'. (2). Setting of place, such as Jakarta, Jambi, Bandung, Purwokerto and etc. (3). Past tense/past perfect tense/ present perfect tense. (4). Adverbs (manner/place/time) represented by the words allegedly, strongly, clearly, and so on. The adverbs of place of headlines and editorials; Jakarta, Medan, Jambi, Bandung, and Purwokerto. The adverb of time that have been used by Jakarta Post are that the years and the days.

d. Affective data The positive feeling of affective data reached $46 \%$ and negative feeling was $54 \%$. And the total number of positive feeling was 154 data and the total number of negative feeling was 175 data. So, the negative feeling was higher than positive feeling.

e. Judgment data. The judgment data showed that the positive judgment was $64 \%$ while the negative judgment was $36 \%$. The total number of positive judgment was 137 data and the total number of negative data was 75 data. So, the judgment data showed significancy. The positive data was higher than the negative data.

f. Value data. The positive value was $49 \%$ and the negative value was $51 \%$. The total number of positive value was 100 data and the total number of negative value was 70 data. So, the positive value was higher than the negative value.

Through the secondary supporting data (interviewed with the board of editor of the Jakarta Post), it was match with (in parallel with) the text analysis I conducted. The Jakarta Post's policy are democratic newspaper (mass media), give accommodation to all group of readers, and cover to both side.

To sum up the affective, judgment and value of the headlines texts, it could be written in the form of a table 1 . 
Table: 1. The following table is the summary of Appraisal (Affective, Judgment, Value) from 23 headlines

\begin{tabular}{cccc}
\hline $\begin{array}{c}\text { Type Of } \\
\text { Appraisal }\end{array}$ & Total & $\begin{array}{c}\text { Negative } \\
(\%)\end{array}$ & $\begin{array}{c}\text { Positive } \\
(\%)\end{array}$ \\
\hline Affective & 329 & $175(54 \%)$ & $\begin{array}{c}154 \\
(46 \%)\end{array}$ \\
& & & 137 \\
Judgment & 212 & $75(36 \%)$ & $(64 \%)$ \\
& & & 100 \\
Value & 173 & $70(51 \%)$ & $(59 \%)$ \\
\hline
\end{tabular}

\section{Conclussion}

The ideology stance of the Jakarta Post tends to support the government (police/authority) of Indonesia when publishing NII's case in the Post through editorials and headlines. But the percentage of the support of the government through its text is not so high comparing with the support to NII. It shows that the Post is democratic newspaper that one of its goals is to give the space for all the groups (the balancing code of ethic in mass media), even the group of NII is illegal group according to the law of Indonesia.

\section{References:}

Abdul Moqsith Gazali. 2011. "Menahan Laju Negara Islam Indonesia”. Kolom Pakar

Media Indonesia 2 Mei 2011. Jakarta: Media Indonesia.

Akbarudin AM. 2013. "Pemikiran RM Kartosoewirjo tentang Republik Indonesia".

Skripsi. Yogyakarta: UIN Sunan Kalijaga.

Ben Kumoring, Usman. 2013. "Kejahatan Altruistik yang Dilakukan oleh Anggota NII Komandemen Wilayah 9 (NII KW 9) dalam Menjalankan Kewajibannya (Studi Kasus Mantan Anggota NII KW 9)". Jakarta: Fisip UI.
Badib, Abbas. 2011. Discourse. Lecture Noted. Unpublished.

Derewianka, Beverly. 1990. Exploring How Text Works. New South Wales: Primary English Teaching Assosciation.

Fairclough, Norman. 2003. Analysing Discourse: Textual Analysis for Social

Research. London and New York: Rouletge.

Hadi, Sofyan. 2013. "NII Konsepsi Shajarah Tayyibah dalam Konstruk Negara Islam". Journal of Qur'an and Hadith Studies - vol 2 No 1 (2013): 87-104.

Hasman. 2013. "Darul Islam (Studi Ide Pembentukan dan Gerakan Negara Islam di Sulawesi Selatan”. Makasar: UIN Alaudin.

Martin, JR and David Rose. 2003. Working with Discourse-Meaning beyond the Clause. New York: Continuum International Publishing Group.

Mubarok \& Dwi Adnjani Made. 2012. "Konstruksi Pemberitaan Media Tentang NII (Analisis Framing Republika dan Kompas)". Jurnal Ilmiah Komunikasi MAKNA Vol 3 No 1, Februari-Juli 2012. Semarang: Unissula Press.

Purwanto, Sugeng. 2009. Around the Fall of Soeharto, a 32-year-period of Indonesian Presidency. An analysis of the rhetorical strategies in Richard Mann's Plot and Scheme that brought down Soeharto (1998) to reveal the struggle of ideology. Germany: VDM Verlag.

Richardson, John E. 2007. Analysing Newspapers. New York: Palgrave Macmillan.

Sutopo, Joko. 2010. Discourse. Lecture Note. Unpublished.

Van Dijk, Teun A. 1979. Text and Context. London: Longman. 